\begin{tabular}{|l|c|c|c|c|}
\hline Submission & Review Process & Revised & Accepted & Published \\
\hline $07-02-2021$ & $17-02$ s/d 15-04-2021 & $25-04-2021$ & $28-04-2021$ & $28-04-2021$ \\
\hline
\end{tabular}

Ampera: A Research Journal on Politics and

Islamic Civilization, Vol. 2 No.2, April 2021 (168-183)

Published by: Politik Islam UIN Raden Fatah Palembang

\title{
Kepemimpinan Tradisional dalam UU Simbur Cahaya di Desa Pajar Bulan Tanjung Batu Ogan Ilir
}

\author{
Bela Fitria \\ Politik Islam Universitas Islam Negeri Raden Fatah Palembang \\ Email: belafitria9816@gmail.com
}

Otoman

Fakultas Adab dan Humaniora Universitas Islam Negeri Raden Fatah Palembang

Email: toraya0009@gmail.com

\begin{abstract}
This paper examines Traditional Leadership in the Simbur Cahaya Law (Case Study: Pajar Bulan Village, Tanjung Batu District, Ogan Ilir Regency). The background of the research problem because leadership is an essential thing which actually needs to be studied in various fields of knowledge. This study seeks to portray the history and forms of traditional leadership that have been applied in Pajar Bulan Village and the relevance of the Simbur Cahaya Law with current leadership. This type of research uses a qualitative research type with various procedures and stages that produce descriptive data. The data sources obtained are primary data and secondary data. Methods of data collection are carried out through interviews, observation and documentation. The data analysis technique used was data reduction, data presentation and conclusion drawing. The conceptual and theoretical framework that the writer uses, namely the concept of leadership and the theory of authority put forward by Max Weber. The results showed that the leadership that had been applied in Pajar Bulan Village before the current leadership was traditional leadership that was based on the Simbur Cahaya Law.

The traditional leadership that has been applied in Pajar Bulan Village is known as krio leadership. In which the selection of a krio was held by means of deliberation and consensus held by community leaders in Pajar Bulan Village. Furthermore, after the election of a krio, it was immediately announced to all levels of society in Pajar Bulan Village and the community immediately agreed to it. In this regard, the traditional leadership system has no influence in the current government leadership in Pajar Bulan Village. Furthermore, the rules of the Simbur Cahaya Law that are still used and have become a tradition in Pajar Bulan Village are some of the rules contained in Chapter 1 (one) of the Simbur Cahaya Law which regulates single, girl and marriage. As for the Simbur Cahaya Law, it is not a legislative product as its name suggests. Which, if viewed in terms of the relevance of the Simbur Cahaya Law to the current leadership of the village
\end{abstract}


head, is the local customary law (pearaturan) that has become a tradition or in other words the customary law regulations from the Simbur Cahaya Law are used as guidelines and pointers.

Keywords: leadership, traditional, simbur cahaya law

\begin{abstract}
ABSTRAK
Tulisan ini mengkaji mengenai Kepemimpinan Tradisional dalam Undang-Undang Simbur Cahaya (Studi Kasus: Desa Pajar Bulan Kecamatan Tanjung Batu Kabupaten Ogan Ilir). Latar belakang masalah penelitian karena kepemimpinan merupakan hal esensial yang sejatinya perlu dikaji di berbagai bidang pengetahuan. Penelitian ini berusaha memotret mengenai sejarah dan bentuk kepemimpinan tradisional yang pernah di terapkan di Desa Pajar Bulan serta relevansi antara Undang-Undang Simbur Cahaya dengan kepemimpinan saat ini. Jenis penelitian menggunakan tipe penelitian kualitatif dengan berbagai prosedur dan tahapan-tahapannya yang menghasilkan data deskriptif. Sumber data yang diperoleh yaitu data primer dan data sekunder. Metode pengumpulan data dilakukan melalui wawancara, observasi dan dokumentasi. Teknik analisis data yang digunakan yaitu reduksi data, penyajian data dan penarikan kesimpulan. Adapun kerangka konseptual dan teoritis yang penulis gunakan yaitu konsep kepemimpinan dan teori otoritas yang dikemukakan oleh Max Weber. Hasil penelitian menunjukkan bahwa kepemimpinan yang pernah diterapkan di Desa Pajar Bulan sebelum kepemimpinan saat ini yaitu kepemimpinan tradisional yang bernaungkan Undang-Undang Simbur Cahaya.
\end{abstract}

Adapun kepemimpinan tradisional yang pernah diterapkan di Desa Pajar Bulan tersebut dikenal dengan kepemimpinan Krio. Yang mana pemilihan seorang Krio digelar dengan cara musyawarah mufakat yang dilakukan oleh para tokoh masyarakat Desa Pajar Bulan. Selanjutnya setelah terpilihnya seorang Krio, langsung diumumkan kepada seluruh lapisan masyarakat Desa Pajar Bulan dan masyarakat langsung menyetujuinya. Berkaitan dengan hal itu, sistem kepemimpinan tradisional tersebut tidaklah mempunyai pengaruh dalam kepemimpinan pemerintahan saat ini di Desa Pajar Bulan. Lebih lanjut, aturan dari Undang-Undang Simbur Cahaya yang masih dipakai dan terealisasi hingga menjadi tradisi di Desa Pajar Bulan adalah beberapa aturan yang dimuat dalam Bab 1 (satu) Undang-Undang Simbur Cahaya yang mengatur tentang bujang, gadis dan kawin. Seperti yang dikesankan oleh namanya, Undang-Undang Simbur Cahaya bukanlah sebuah Undang-Undang yang dalam artian sebuah produk legislatif dari suatu Dewan Perwakilan Rakyat. Dalam sejarahnya pada tahun 1832 Overste de Brauw menuturkan bahwa dari peraturan hukum adat yang berupa kodifikasi tersebut yang bahwasanya dibuat oleh Van den Bossche yaitu final dalam waktu 3 (tiga) kali rapat. Berkaitan dengan hal ini, bahwa konsep dari kodifikasi tersebut dibacakan, kemudian disetujui oleh Residen. Adapun peninjauan kembali terkait kodifikasi tersebut dirumuskan dalam sebuah rapat yang dihadiri oleh kepala-kepala rakyat dari tanggal 2 s/d 6 September 1927 yang bertempat di Palembang. Hasil dari rapat tersebut membuahkan penerbitan baru dari Undang-Undang Simbur Cahaya dan kemudian hari terus ditambah dan dirubah. Lebih lanjut, bahwa jika dilihat dari segi relevansi Undang-Undang Simbur Cahaya terhadap kepemimpinan kepala desa saat ini adalah hukum adat (peraturan) yang berlaku setempat yang sudah menjadi tradisi atau dalam kata lain peraturan hukum adat dari UndangUndang Simbur Cahaya tersebut dijadikan sebagai pedoman dan penunjuk. 
Keywords: kepemimpinan, tradisional, undang-undang simbur cahaya

\section{PENDAHULUAN}

Negara adalah sebuah himpunan keluarga maupun desa yang berguna dengan tujuan mendapatkan hidup yang lebih baik (Aristoteles). Adapun desa merupakan sebuah bagian terkecil dari Negara, pemerintahan pusat selalu berupaya dalam mengembangkan dan memajukan sebuah desa yaitu ditandai dari kebijakan-kebijakan yang ditujukan terhadap pedesaan. Hak-hak otonomi diberikan sepenuhnya kepada desa dalam mengurus dan mengatur rumah tangganya sendiri dalam upaya penyelenggaraan pemerintahan desa guna mencapai sebuah kamajuan desa.

Kemandirian yang dimiliki desa yang berupa mengurusi pemerintahan serta juga desa mempunyai sistem adat yang bisa mengatur masyarakatnya (masyarakat mematuhi tatanan tersebut). Namun pada saat dikeluarkan Undang-Undang yang mengatur tentang Pemerintahan Desa atau dengan kata lain pada masa orde baru, Indonesia menyeragamkan bentuk pemerintahan desa yaitu dengan Undang-Undang Nomor 5 Tahun 1979. Berkaitan dengan hal tersebut, bahwa secara tidak langsung bentuk pemerintahan adat-istiadat yang selama ini digunakan tidak diakui lagi.

Desa Pajar Bulan Kecamatan Tanjung Batu Kabupaten Ogan Ilir yaitu desa peneliti, yang mana sebelum dikeluarkan Undang-Undang Nomor 5 Tahun 1979 pernah menjalankan bentuk pemerintahan dengan memakai Undang-Undang Simbur Cahaya atau dengan kata lain memakai bentuk kepemimpinan tradisional yang mana dalam hal ini sistem pemerintahannya dalam bentuk marga dengan seorang Proatin (Krio) sebagai kepala dusun atau sekarang di sebut kepala desa. Kepemimpinan tradisional tersebut salah satu yang memberi pengaruh terhadap penyelenggaraan pemerintahan dusun atau yang disebut dengan desa. Adapun dinamika pemilihan kepala dusun tersebut dipilih secara demokratis sesuai dengan peraturan adat yang berlaku. Yang mana pemilihan kepala dusun digelar dengan musyawarah mufakat yang dilakukan oleh tokoh masyarakat Desa Pajar Bulan. Kemudian hasil dari musyawarah mufakat tersebut langsung diumumkan kepada seluruh masyarakat Desa Pajar Bulan dan masyarakat langsung menyetujuinya.

Berkaitan dengan hal tersebut, tokoh masyarakat yang memilih kepala dusun tersebut berasal dari orang-orang yang mempunyai pengaruh, berwibawa dan berkharisma. Yang sehingga membuat seluruh masyarakat menyetujui akan keputusan atau pilihan dari tokoh masyarakat yang ada di Desa Pajar Bulan tersebut. Kemudian juga berkaitan dengan hal itu, semua lapisan masyarakat ikut andil membantu, bahu membahu dalam penyelenggaraan pembangunan desa.

Ketika sistem pemerintahan dusun diganti menjadi pemerintahan desa, terdapat perubahan yang signifikan yang menyebabkan memiliki pengaruh maupun dampak terhadap sistem adat tersebut. Dusun yang menganut sistem adat mulai berangsur melemah sebab pengaruh modernisasi, serta juga mulai menghilangnya nilai kearifan lokal dalam membangun kesejahteraan dusun (desa). Sehubungan dengan hal ini, kepemimpinan adat sangatlah penting sebab bisa memberi pengaruh akan terlaksananya pemerintahan dusun (desa), karena dasar ia memimpin dengan hati nurani dan tidak terikat dengan birokrasi.

Sebuah desa tidaklah mungkin menjalankan roda kehidupan dan roda pemerintahan dengan apa adanya atau dengan kata lain tidak memiliki seorang pemimpin. Seperti halnya dijelaskan dalam sebuah hadist berikut ini : "Tidak diperbolehkan di muka bumi ini bagi tiga orang yang berada di tempat terbuka kecuali diantara satu dari mereka yang 
menjadi pemimpin mereka" (H. R. Ahmad). "Jika terdapat tiga orang berjalan keluar bepergian maka salah satu dari mereka harus menjadi pemimpin mereka" (H. R. Abu Daud).

Pengaruh dari Undang-Undang Simbur Cahaya sangatlah besar dalam kehidupan masyarakat di Desa Pajar Bulan. Sebab Undang-Undang Simbur Cahaya mengandung sebuah nilai-nilai kehidupan yang berlaku di Desa Pajar Bulan, serta juga dapat memberikan dampak baik bagi kehidupan maupun pemerintahan di Desa Pajar Bulan. Berkaitan dengan hal tersebut, peneliti merasa bahwa sebuah keharusan untuk mengetahui lebih mendalam mengenai Bagaimana Kepemimpinan Tradisional dalam Undang-Undang Simbur Cahaya di Desa Pajar Bulan Kecamatan Tanjung Batu Kabupaten Ogan Ilir.

\section{TINJAUAN LITERATUR}

Penelitian tentang Kepemimpinan Tradisional dalam Undang-Undang Simbur Cahaya di Sumatera Selatan belum banyak yang melakukannya. Namun terdapat beberapa penelitian yang secara umum senada dengan penelitian yang telah dilakukan diantaranya sebagai berikut : Penelitian dari saudara Muhammad Frengky dari Universitas Islam Negeri Raden Fatah Palembang dengan sebuah judul "Perbandingan Kepemimpinan Modern dan Kepemimpinan Adat Semende Desa Cahaya Alam Muara Enim. Kesimpulan dalam penelitian ini bahwasanya terdapat perbandingan kepemimpinan Adat Semende di Desa Cahaya Alam yang berlaku terdiri dari dua bentuk kepemimpinan yaitu : Kepemimpinan yang mencakup satu desa dan kepemimpinan dalam keluarga atau sekarang di sebut dengan Kepemimpinan Tunggu Tubang. Terdapat perbandingan lembaga Kepemimpinan Adat Semende Tradisional dan Kepemimpinan Adat Semende di era modern sekarang ini. Kepemimpinan Tradisional Semende mempunyai dua bentuk sistem Kepemimpinan Adat yaitu Kepemimpinan Adat secara umum (Kepemimpinan yang mencakup satu desa) dan Kepemimpinan dalam Keluarga (Kepemimpinan Tunggu Tubang). Adapun pada kepemimpinan Semende di era modern sekarang sudah mempunyai lembaga tersendiri yang lebih terstruktur dan tidak lagi bergabung dengan lembaga pemerintahan seperti sebelum tahun 1983.

Penelitian dari saudara Hadi Mustafa dari Universitas Islam Negeri Syarif Hidayatullah Jakarta dengan sebuah judul "Kepemimpinan Kharismatik : Studi Kepemimpinan Politik Megawati Soekarno Putri dalam Partai Demokrasi Indonesia Perjuangan (PDIP). Kesimpulan dalam penelitian ini bahwasanya sosok Megawati Soekarno Putri adalah sosok pemimpin yang berkarisma, sebab terdapat nilai-nilai kepribadian yang baik, teguh dalam berprinsip. Megawati dalam menjalankan tugasnya sebagai seorang pemimpin berpegang teguh kepada 4 pilar berbangsa dan bernegara. Dalam penelitian ini dapat diambil intisarinya bahwa seorang pemimpin harus mempunyai pedoman dalam menjalankan tugasnya sebagai seorang pemimpin dan harus mempunyai tujuan dengan prioritas yang teratur, jelas dan terarah.

Penelitian dari saudara Ardiansyah dari Universitas Islam Negeri Sultan Thaha Saifuddin Jambi dengan sebuah judul "Pengaruh Kepemimpinan Adat Terhadap Pelaksanaan Pemerintahan Desa". Kesimpulan dalam penelitian ini bahwasanya sistem kepemimpinan itu bertujuan untuk kepentingan bersama. Kepemimpinan adat di Desa Penapalan lebih mengedepankan nilai gotong royong yang dalam hal ini terkenal dengan sebutan berat samo di pikul, ringan samo di jinjing. Adapun landasan memimpin dalam penelitian ini adalah berlandaskan kepada Syariat, Pancasila dan Adat Istiadat. 
Penelitian dari saudara Ainal Yaqin dari Universitas Islam Negeri Raden Intan Lampung dengan sebuah judul "Kepemimpinan Adat Semendo dalam Perspektif Fiqih Siyasah". Kesimpulan dalam penelitian ini bahwasanya kepemimpinan adat Semendo yang memiliki kepemimpinan adat di Suku Uludanau. Adapun mekanisme pemilihan ketua adat pada Suku Uludanau dipilih berdasarkan musyawarah yang dilakukan oleh masyarakat Semendo. Ditinjau dari perspektif Fiqih Siyasah bahwa Suku Semendo yang menerapkan kepemimpinan adat tersebut mempunyai kesesuaian yaitu setiap individu berhak untuk mencalonkan diri menjadi seorang pemimpin dengan berdasarkan asas demokrasi.

Penelitian dari saudari Yulida Leza dari Universitas Islam Negeri Raden Intan Lampung dengan sebuah judul "Kepemimpinan Adat Lampung dalam Perspektif Fiqih Siyasah". Kesimpulan dari penelitian ini bahwasanya Pekon Pagar Dalam memiliki bentuk kepemimpinan adat yang disebut Saibatin, yang berarti satu batin dalam arti lain memiliki satu junjungan dengan tatanan sosial. Saibatin (kepala adat) ini mendapatkan jabatan sebagai seorang pemimpin dengan berdasarkan budaya yang berlaku yaitu diwariskan berdasarkan garis keturunan (Monarki).

Penelitian dari saudara Muhammad Aedil Akbar dari Universitas Islam Negeri Alauddin Makassar dengan sebuh judul "Elit Berkuasa dan Kepemimpinan Tradisional" (Studi Kasus: Relasi Kuasa antara Pemerintah Takalar dengan Karaeng Galesong). Kesimpulan dalam penelitian ini bahwasanya di masyarakat Takalar di Kecamatan Galesong mempunyai seorang penguasa (Karaeng) atau dalam kata lain pemimpin yang memiliki kharisma. Adapun faktor moral merupakan faktor yang sangat menentukan berjaya dan tidak berjayanya seorang pemimpin di masyarakat.

Berdasarkan beberapa penelitian diatas yang membedakan tulisan peneliti dengan tulisan sebelumnya adalah ini mengkaji mengenai Kepemimpinan Tradisional dalam Undang-undang Simbur Cahaya (Studi Kasus : Desa Pajar Bulan Kecamatan Tanjung Batu Kabupaten Ogan Ilir). Dengan menggunakan pendekatan kualitatif, penelitian dilakukan dengan cara observasi dan wawancara langsung kepada tokoh masyarakat Desa Pajar Bulan. Hasil studi menunjukkan bahwa kepemimpinan tradisional yang pernah diterapkan di Desa Pajar Bulan merujuk kepada teori otoritas tradisional yang dikemukakan oleh Max Weber yang memiliki arti bahwa otoritas ini yang bersumber dari masyarakat atau dalam kata lain bersumber dari kebudayaan serta kebiasaan (adat istiadat) yang berlaku di masyarakat. Adapun dalam dinamika pemilihan Krio di Desa Pajar Bulan ini berhubungan dengan teori yang di kemukakan oleh Max Weber yaitu otoritas kharismatik yang berarti bahwa sebuah otoritas yang berasal dari sesuatu yang istimewa dan juga bisa dikatakan sesuatu yang unik yang diakui oleh orang lain. Yang mana otoritas ini mempunyai sebuah keunggulan dan terjamin kepemimpinannya.

\section{METODE PENELITIAN}

Dalam penelitian ini, metode penelitian yang digunakan adalah metode kualitatif dengan riset penelitian yang bersifat deskriptif. Adapun penelitian dengan metode kualitatif ini adalah metode yang berproses dengan tahap pengumpulan data yang dilakukan secara bersamaan dalam proses penelitian tersebut. Suatu metode penelitian merupakan cara ilmiah dalam upaya mendapatkan beberapa data dengan tujuan yang tertentu. Adapun peneliti diberi kebebasan memilah mengenai metode apa yang akan digunakan dalam sebuah penelitiannya atau dalam kata lain sesuai dengan tujuan penelitian yang dilakukan. Berkaitan dengan hal ini, metode penelitian mencakup alat dan prosedur penelitian yang 
berguna untuk memandu peneliti dalam melakukan penelitian sesuai dengan urutan kerja yaitu mulai dari tahap awal hingga menuju tahap akhir penelitian.

Penelitian kualitatif menurut Straruss dan Corbin merupakan penelitian yang di peroleh dari menghasilkan suatu penemuan atau dalam kata lain tidak di dapat dengan cara maupun prosedur pengukuran. Penelitian kualitatif secara umum dapat digunakan dalam penelitian yang ruang lingkupnya adalah kehidupan di masyarakat yang berupa aktivitas, tingkah laku, sejarah, sosial dan lain sebagainya.

Adapun penelitian yang akan dilakukan peneliti dibuat dengan mengajak dan berusaha memotret tentang keadaan sesungguhnya mengenai bagaimana kepemimpinan tradisional yang pernah diterapkan di Desa Pajar Bulan dengan bernaungkan UndangUndang Simbur Cahaya.

\section{HASIL DAN PEMBAHASAN}

Kepemimpinan pada dasarnya bersifat menyentuh dan menyeluruh dari berbagai aspek kehidupan. Kepemimpinan adalah suatu konsekuensi dari kehidupan yang bersifat masuk akal dalam peradaban kehidupan manusia dari masa pra modern hingga modern, baik dari konteks religi hingga sosial dan politik pasti berkaitan dengan sebuah kepemimpinan, sehingga dengan jelas bahwasanya kepemimpinan itu merupakan hal esensial yang sejatinya perlu dikaji di berbagai bidang pengetahuan.

Dilihat dari berbagai sudut pendekatan Thoha menuturkan bahwa pada dasarnya kepemimpinan menimbulkan definisi yang berbeda di setiap pendekatan. Kepemimpinan sangatlah dibutuhkan oleh manusia sebagai makhluk sosial sebab manusia sejatinya ada yang mempunyai kelebihan dan sebaliknya. Berkaitan dengan hal ini, bahwa manusia ada yang mempunyai kemampuan untuk memimpin dan ada pula yang tidak mempunyai kemampuan untuk memimpin.

Sudria Munawar menugemukakan bahwa berikut hal-hal yang perlu diperhatikan dalam konsep kepemimpinan, diantaranya :

a. Kewibawaan adalah suatu kelebihan yang di bilang istimewa yang dimiliki oleh seorang pemimpin. Dengan adanya kelebihan ini membuat orang lain untuk ikut andil dan bersedia melakukan kerja sama dalam kegiatan yang dikehendakinya.

b. Kemampuan adalah suatu keterampilan teknis maupun sosial yang melebihi keterampilan orang lain.

c. Kekuasaan adalah kewenangan bagi seorang pemimpin dalam menggerakkan seorang individu maupun kelompok supaya mau melakukan kerja sama dalam upaya mencapai suatu tujuan yang sebelumnya telah direncanakan bersama.

Sebuah kepemimpinan sangat berhubungan erat dengan sebuah pemerintahan, karena dimana ada pemerintahan pasti di dalamnya terdapat sebuah kepemimpinan. Yang mana guna sebuah kepemimpinan tersebut adalah mengendalikan serta mengatur jalannya sebuah pemerintahan supaya berjalan sesuai dengan koridornya.

Salah satu fungsi pemerintahan dibentuk guna menghindari sebuah kekacauan di dalam suatu wilayah tertentu yang didalamnya terdapat sekelompok masyarakat atau sebuah komunitas penduduk yang beragam dan memiliki perbedaan dalam setiap pandangan. Berkaitan dengan hal inilah kemudian terbentuk suatu kelompok terkuat guna menjadi pelindung dari gangguan kelompok yang lainnya. Maka dari itu, kelompok 
terkuat ini diartikan sebagai pemerintah, atau dengan kata lain pemerintah adalah sekelompok orang yang mempunyai tanggung jawab atas sebuah kekuasaan.

Adapun peran pemerintah yang memelihara keamanan dan kedamaian Negara yang menjadi keutamaan dalam sebuah kewenangan dari aspek internal hingga eksternal. Berkaitan dengan hal ini, Max Weber menuturkan bahwa pemerintah merupakan tidak lain dari apapun yang berhasil menopang perspektif bahwa dialah yang berhak menggunakan kekuatan fisik secara eksklusif dalam suatu wilayah untuk memberlakukan aturan-aturan tertentu yang telah dibuat.

Dilihat dari aspek managemen bahwa pemerintah mempunyai fungsi-fungsi antara lain: fungsi memberi arahan dan petunjuk, memimpin, menggerakkan, mengkoordinasi, mengawasi serta memotivasi dalam hubungan pemerintahan. Karl W Deutsh menuturkan bahwa dalam kegiatan penyelenggaraan pemerintahan diibaratkan seperti mengemudi sebuah kapal yang besar di tengah samudera. Berkaitan dengan hal ini, Ayhena juga mengemukakan bahwa fungsi sebuah pemerintahan dapat kita jumpai dalam konstitusi, diantara fungsinya yaitu: fungsi perencanaan anggaran belanja, pajak, militer serta fungsi peradilan. Lain halnya dengan Rasyid yang menuturkan bahwa untuk melihat pemerintahan, maka lihatlah masyarakatnya yang memiliki makna bahwa pemeritahan yang diterapkan akan menentukan kualitas dari pemerintahan tersebut. Adapun fungsinya dibagi ke dalam empat kriteria antara lain: pemberdayaan, pelayanan, pengaturan dan pembangunan.

Adapun dalam pandangan Islam, kepemimpinan adalah sebuah tanggung jawab yang harus diemban dan dipertanggung jawabkan di hadapan Allah SWT dan juga dipertanggung jawabkan di hadapan sesama manusia. Berkaitan dengan hal tersebut, bahwa kepemimpinan bukanlah sesuatu perihal yang menggembirakan, sebab terdapat banyak amanah yang harus diemban dengan sebaik-baiknya. Deliar Noer menuturkan terkait hal prinsip etika politik kepemimpinan Islam, bahwasanya seorang pemimpin harus menjalankan beberapa point meliputi: Al-Qur'an dan Sunnah, Syari'at (Hukum), prinsip syura, prinsip kebebasan serta memiliki toleransi antar umat beragama.

Dari beberapa prinsip diatas, bahwa seorang pemimpin dalam suatu Negara demokrasi harus memiliki moral yang baik dalam kepemimpinan yang dijalankan. Berkaitan dengan hal ini, menurut pandangan penulis bahwa kepemimpinan dalam perspektif Deliar Noer mengharuskan seseorang memiliki moral dan norma kepemimpinan dari seorang pemimpin itu sendiri. Dengan demikian, akan tercipta suatu keadaan yang damai dan efektifitas dari kepemimpinan itu sendiri memiliki pengaruh ke arah yang lebih baik dalam konteks kemajuan suatu desa, kota bahkan Negara.

Lain halnya dengan Max Weber yang mengemukakan teori otoritas, diantara teori tersebut antara lain :

a. Otoritas Legal

Otoritas legal adalah sebuah otoritas yang bersumber dari aturan yang diberlakukan. Bahwa otoritas ini dijalankan pada Negara modern yang memiliki perserikatan badan hukum atau dalam kata lain milik sendiri.

b. Otoritas Tradisional

Otoritas tradisional adalah sebuah otoritas yang berdasarkan adat istiadat atau dalam kata lain tradisi yang berkembang yang sudah lama ada dikehidupan masyarakat. Bahwa otoritas ini termasuk ke dalam peraturan yang turun temurun dan berasal dari kepercayaan yang telah lama dijalani.

c. Otoritas Kharismatik 
Otoritas kharismatik adalah sebuah otoritas yang unsur utamanya berupa kemampuan khusus yang ada pada diri seseorang atau dalam kata lain sebuah kharisma yang dimiliki yang diakui oleh orang lain. Bahwa otoritas ini sudah terjamin kepemimpinannya karena mempunyai sebuah keistimewaan dan keunggulan

\section{Kepemimpinan Tradisional di Desa Pajar Bulan}

Dalam konteks kepemimpinan tradisional pasti berhubungan erat dengan Kesultanan Palembang. Dalam mengkaji tentang Palembang, kita harusnya memiliki sebuah pemahaman mengenai wilayah yang berada di Sumatera Selatan yaitu dibagi dengan berdasarkan ekologi dan penyebab terbentuknya kebudayaan dan struktur sosial di daerah. Adapun daerah Palembang terbagi menjadi 2 (dua) wilayah yaitu Uluan dan Iliran. Yang mana kedua wilayah tersebut menjadi sebuah pembeda antara dataran tinggi dan dataran rendah.

Kabupaten Ogan Ilir atau dahulu yang tergabung dalam Kabupaten Ogan Komering Ilir adalah sebuah wilayah pedalaman Palembang (Uluan). Pada masa itu, wilayah ini di bawah kendali pemerintahan Kesultanan Palembang. Berkaitan dengan hal ini, bahwa bentuk pemerintahan yang dijalankan adalah dengan sisem marga.

Adapun masyarakat Desa Pajar Bulan memulai pemerintahan dengan sistem marga tersebut pada Tahun 1930 yang pada masa itu ditandai dengan Cek Magok yang dipilih menjadi Krio pertama yang menjabat di Desa Pajar Bulan. Berkaitan dengan hal ini, bahwa pemerintahan dengan sistem marga berjalan sudah cukup lama. Adapun pada tahun 1983 keluar Surat Keputusan Gubernur Daerah Tingkat I Sumatera Selatan Nomor 142 / KPTS / III / 1983 tentang penghapusan pemerintahan dengan sistem marga.

Di Desa Pajar Bulan mulai merealisasikan pemerintahan modern atau dalam kata lain penghapusan sistem marga yaitu pada tahun 1985 yang dalam hal ini ditandai dengan diangkatnya seorang krio yang pada masa itu masih menjabat. Proses pengangkatan Bapak Rasyid menjadi kepala desa pada masa itu di gelar dengan musyawarah mufakat terlebih dahulu yang dilakukan oleh masyarakat Desa Pajar Bulan.

Terhitung lebih kurang setengah abad Desa Pajar Bulan menerapkan pemerintahan dengan sistem marga yang berpacu kepada Undang-Undang Simbur Cahaya. Berkaitan dengan hal ini, bahwa aturan khusus yang mengatur tentang marga yaitu terdapat dalam Bab 2 (dua) Undang-Undang Simbur Cahaya. Yang mana dalam Undang-Undang Simbur Cahaya disebutkan untuk kepala marga di pimpin oleh seorang Pasirah. Sedangkan untuk kepala dusun dipimpin oleh seorang Proatin (Krio). Adapun sebelum adanya kepemimpinan Krio ini, Desa Pajar Bulan memiliki kepemimpinan yaitu kepemimpinan seorang ketua talang.

Adapun penulis dapat menganalisa bahwa sejarah kepemimpinan tradisional yang pernah diterapkan di Desa Pajar Bulan merujuk kepada teori otoritas tradisional yang dikemukakan oleh Max Weber yang memiliki arti bahwa otoritas ini yang bersumber dari masyarakat atau dalam kata lain bersumber dari kebudayaan serta kebiasaan (adat istiadat).

\section{Dinamika Pemilihan Krio di Desa Pajar Bulan}

Kepemimpinan dalam Kitab Simbur Cahaya terdiri dari unsur yang paling rendah hingga yang tertinggi. Yang mana unsur terkecil kepemimpinan yaitu sebuah dusun yang dipimpin oleh Krio (Proatin). Terdapat kampung dalam sebuah dusun tersebut yang 
membentuk kesatuan hidup yang berasal dari satu keturunn yang berupa kelompokkelompok kemudian membentuk marga yang dikepalai oleh seorang Pasirah.

Dalam Kitab Simbur Cahaya terdapat aturan kepemimpinan Krio. Yang mana Undang-Undang Simbur Cahaya tersebut bukanlah sebuah produk legislatif seperti yang dikesankan oleh namanya. Melainkan Undang-Undang Simbur Cahaya tersebut adalah hukum adat yang berdasarkan tatanan kemasyarakatan tradisional. Yang mana tatanan dari Undang-Undang Simbur Cahaya ini berlaku di seluruh wilayah pedalaman yang ada di Sumatera Selatan terkhusus pada kehidupan masyarakat Kabupaten Ogan Komering Ilir.

Adapun di Desa Pajar Bulan, kepemimpinan tradisional yang pernah diterapkan yaitu kepemimpinan Krio dengan bernaungkan kepada Undang-Undang Simbur Cahaya. Berkaitan dengan hal tersebut, menurut peneliti bahwa kepemimpinan Krio adalah kepemimpinan tradisional yang muncul dari sebuah tatanan sosial dengan berbagai pengaruh atau dalam kata lain kharisma yang dimiliki oleh pemimpin itu sendiri.

Di kehidupan masyarakat tradisional, pemimpin memperoleh otoritasnya melalui garis keturunan dari orang tuanya (jabatan pimpinan dari orang tuanya) atau lebih dikenal dengan istilah Monarki. Hal tersebut menjadi landasan terkait kepercayaan masyarakat tentang pewarisan kekuasaan diperoleh dari garis keturunan atau faktor keluarga. Adapun pemerintahan yang turun temurun tersebut adalah sebuah kebiasaan masyarakat dalam memilih seorang pemimpin yang berdasarkan hubungan kekeluargaan serta kekerabatan. Di Desa Pajar Bulan, dalam kehidupan masyarakatnya terkait hal kepemilikan tahta kekuasaan yang dimiliki seseorang selain dengan jalan pewarisan kekuasaan berdasarkan dari faktor keluarga dan garis keturunan, juga diperoleh dengan jalan demokrasi yang dilakukan masyarakat yaitu berupa musyawarah mufakat dengan berbagai syarat serta ketentuan yang harus ditempuh oleh calon pemimpin dalam sebuah dusun tersebut.

Di Desa Pajar Bulan, mekanisme pemilihan Krio di pilih secara demokratis sesuai dengan aturan yang berlaku, yang bahwasanya proses pemilihan Krio tersebut harus di musyawarah dan di mufakatkan terlebih dahulu oleh para tokoh masyarakat yang berada di Desa Pajar Bulan. Kemudian setelah Krio terpilih, selanjutnya langsung diumumkan hasil tersebut kepada seluruh lapisan masyarakat Desa Pajar Bulan dan masyarakat langsung menyetujuinya. Yang mana bahwasanya pemilihan Krio di Desa Pajar Bulan ini berhubungan dengan teori yang di kemukakan oleh Max Weber yaitu otoritas kharismatik yang berarti bahwa sebuah otoritas yang berasal dari sesuatu yang istimewa dan juga bisa dikatakan sesuatu yang unik yang diakui oleh orang lain. Yang mana otoritas ini mempunyai sebuah keunggulan dan terjamin kepemimpinannya.

Penulis dapat menganalisa bahwa pemilihan Krio di Desa Pajar Bulan ini berhubungan dengan teori yang di kemukakan oleh Max Weber yaitu otoritas kharismatik yang berarti bahwa sebuah otoritas yang berasal dari sesuatu yang istimewa dan juga bisa dikatakan sesuatu yang unik yang diakui oleh orang lain. Yang mana otoritas ini mempunyai sebuah keunggulan dan terjamin kepemimpinannya. Adapun dari teori otoritas tradisional dan otoritas kharismatik yang dikemukakan oleh Max Weber bahwa korelasinya dengan Undang-undang Simbur Cahaya adalah karena Undang-undang Simbur Cahaya merupakan kumpulan hukum adat yang dalam hal ini berkaitan dengan teori otoritas tradisional, sedangkan otoritas kharismatik berkaitan dengan Undangundang Simbur Cahaya yaitu pada peran figur dan ketokohan Krio tersebut dalam menjalankan perannya sebagai seorang pemimpin.

Adapun saat ini setelah status dusun berganti menjadi desa, terdapat perbedaan dalam segi memilih seorang pemimpin. Yang mana desa dipimpin oleh seorang kepala 
desa. Berkaitan dengan hal tersebut, bahwa pemilihan kepala desa diatur dalam UndangUndang Nomor 6 Tahun 2014 Tentang Pemerintahan Desa bahwa pemilihan kepala desa dipilih secara langsung oleh dan dari penduduk Desa warga Negara Republik Indonesia yang memenuhi persyaratan dengan masa jabatan 6 (enam) tahun terhitung sejak tanggal pelantikan. Kepala Desa dapat menjabat paling banyak 3 (tiga) kali masa jabatan secara berturut-turut atau tidak secara berturut-turut. Berkaitan dengan hal tersebut, bahwa pengangkatan dan pemberhentian kepala desa juga diatur dalam Peraturan Daerah (Perda) Kabupaten Ogan Ilir Nomor 4 Tahun 2017 tentang pengangkatan dan pemberhentian kepala desa.

\section{Sistem Kepemimpinan Krio di Desa Pajar Bulan}

Makna dari sistem kepemimpinan adalah bagaimana cara seorang pemimpin dalam manjalankan fungsi kepemimpinannya. Berkaitan dengan hal tersebut, bahwa pemimpin diharuskan memiliki kecakapan untuk "menafsir" atau dalam kata lain membaca situasi yang dihadapinya dengan cepat dan tepat serta bisa menyesuaikan dengan situasi dan kondisi yang ada.

Berikut beberapa tipe sistem kepemimpinan, antara lain:

a. Tipe Kepemimpinan Otokratis.

Seorang pemimpin pada tipe ini cenderung memandang sebuah organisasi itu sebagai milik pribadinya, cenderung memandang bahwa seorang bawahan adalah alat sematamata serta mengidentikkan tujuan dari organisasi dengan tujuan pribadinya, tidak mau menerima masukan, kritik, saran serta pendapat dari orang lain serta pada segi tindakan pemimpin dengan tipe ini sering memberi perintah dengan jalan pemaksaan.

Yang dibahas mengenai tipologi kepemimpinan yaitu dengan pemahaman literatur, bahwa seorang pemimpin dengan tipe kepemimpinan otokratis mempunyai beberapa ciri karakteristik yang dipandang sebagai karakteristik yang kurang baik. Dari aspek persepsinya, seorang pemimpin dengan tipe kepemimpinan ini yaitu seseorang yang memiliki sifat egoisme yang sangat tinggi. Yang mana dari sifat egoisnya tersebut akan mendorongnya untuk melakukan segala cara yang membuat posisinya aman, walaupun dengan jalan memutar balikkan fakta sekalipun.

b. Tipe Kepemimpinan Paternalistik.

Seorang pemimpin dengan tipe kepemimpinan paternalistik dapat kita temui di sebuah kehidupan yang masih tradisional. Adapun berbagai faktor mengenai popularitas kepemimpinan dengan tipe ini, meliputi: kuatnya hubungan seorang anggota masyarakat yang satu dengan masyarakat yang lainnya, peran dari adat istiadat yang masih sangat kuat di kehidupan masyarakatnya, serta ikatan primordialisme yang masih sangat kuat.

c. Tipe Kepemimpinan Demokratis.

Seorang pemimpin yang aktif, dinamis serta bertanggung jawab selalu bersedia saat diberi masukan, nasihat, serta saran dari seorang bawahannya dan juga sangat menghargai hal tersebut. Sementara pada proses mengambil sebuah keputusan dilakukan dengan cara musyawarah dan mufakat serta yang terpenting selalu mengahargai seorang bawahan dengan bersikap yang manusiawi.

Dikalangan ilmuan dan juga dikalangan praktisi terdapat konsensus mengenai tipe kepemimpinan yang paling ideal dan juga yang terbaik yaitu seorang pemimpin dengan tipe kepemimpinan demokratis. Yang mana tipe kepmimpinan demokratis ini 
adalah tipe kepemimpinan yang efektif dan ideal dalam kehidupan yang berorganisasi dan berkelompok.

D. Tipe Kepemimpinan Laisez Faire

Seorang pemimpin dengan tipe ini cenderung menunjukkan sikap yang sering menghindar dari sebuah tanggung jawab yang harus diemban, berkelakuan pasif serta sering membiarkan organisasi berjalan sesuai temponya sendiri atau dalam kata lain mengalir saja dengan apa adanya. Yang mana kedudukan seorang pemimpin tersebut hanya sebuah simbol dan formalitas belaka, sementara dalam hal terkait pengambilan sebuah keputusan cenderung memberikan kebebasan yang sepenuhnya kepada anggota/kelompok.

Seorang pemimpin dengan tipe kepemimpinan kendali bebas ini beranggapan bahwa perannya yang sebagai seorang pemimpin tidak jauh dari persepsi bahwa pada umumnya organisasi akan berjalan dengan baik sebab tujuan dari organisasi yaitu pencapaian suatu tujuan yang telah direncanakan oleh para anggota organisasi bersama pemimpinnya. Dalam hal ini pemimpin dan anggota dari organisasi tersebut tidaklah terlalu sering melakukan peninjauan kembali dan intervensi terkait apa yang telah direncanakan tersebut. Dalam artian bahwasanya seorang pemimpin dengan tipe kepemimpinan ini menganggap perannya ibarat "Polisi Lalu Lintas" yang mana para anggota dari organisasi tersebut sudah cukup dewasa juga sudah memahami terkait peraturan yang berlaku atau dalam kata lain tidak banyak komentar terkait hal bagaimana organisasi tersebut harus digerakkan.

Seorang pemimpin dengan tipe ini memiliki berbagai nilai-nilai yang dianut dalam menjalankan kepemimpinannya yaitu lebih sering bertentangan dengan hakikat hidup bahwa pada umumnya manusia memiliki solidaritas dalam kehidupan masyarakat yang berkelompok dan beragam, mempunyai kesetiaan kepada sesama anggota serta organisasi, taat dan patuh terhadap berbagai norma yang berlaku di kehidupan masyarakat serta mempunyai jiwa pertanggung jawaban yang besar terhadap tugas yang harus dijalankannya.

Dari berbagai kriteria dalam tipe kepemimpinan tersebut terdapat ciri tertentu yang mengklasifikasikan antara tipe kepemimpinan yang satu dengan tipe kepemimpinan yang lainnya. Adapun berbagai pendekatan yang dipakai dalam upaya menganalisa dari keempat tipe ini. Berikut cara yang digunakan dalam upaya menganalisa serangkaian karakter yang dimiliki seseorang pada tipe kepemimpinan adalah dengan cara melaksanakan pengkategorian dari beberapa karakter tersebut dengan berdasarkan : a. Pandangan dan persepsi seorang pemimpin mengenai tugas dan perannya sebagai seorang pemimpin. B, Perilaku seorang pemimpin dalam manjalankan kepemimpinannya. C. Nilai-nilai yang dianut oleh seorang pemimpin, dan d, Sikap dalam menjalankan organisasi atau pemerintahan.

Dengan serangkaian pendekatan diatas, bahwa semakin terlihat jelas mengenai tipe kepemimpinan yang memiliki lebih banyak ciri karakteristik yang bernilai positif. Yang mana tipe kepemimpinan yang dimaksud yaitu tipe kepemimpinan demokratik. Walaupun juga terdapat kekurangan dan kelemahan tertentu dari tipe kepemimpinan ini.

Adapun penulis dapat menganalisa bahwa di Desa Pajar Bulan memiliki sistem kepemimpinan Krio yang termasuk ke dalam tipe kepemimpinan demokratik dan paternalistik. Dalam kedua tipe kepemimpinan ini yang menjadi dasar utama yaitu peran adat istiadat dalam kehidupan bermasyarakat yang tergolong masih sangat kuat, dalam mengambil suatu keputusan selalu di dasari oleh musyawarah dan mufakat serta yang 
paling utama budaya gotong royong yang melekat dengan sangat kuatnya dalam kehidupan di Desa Pajar Bulan.

Penulis dapat menarik intisarinya bahwa bentuk dari kepemimpinan demokratik dan paternalistik itu adalah dilihat dari aspek kehidupan masyarakatnya yang memiliki nilai budaya kegotong royongan yang sangat kuat. Bahwasanya makna gotong royong dalam hal ini adalah sama seperti makna demokratik yaitu dari rakyat, oleh rakyat dan untuk rakyat atau dalam kata lain bersumber dari masyarakat. Sedangkan pada kepemimpinan paternalistik adalah peran adat istiadat yang masih sangat kuat yaitu dengan ditandai dengan pengaturan desa bahwa desa saat itu dibawah naungan Undangundang Simbur Cahaya. Bahwasanya Undang-undang Simbur Cahaya merupakan kumpulan hukum adat yang berlaku di uluan Palembang. Yang mana Desa Pajar Bulan pada waktu itu tergabung dalam Marga Tanjung Batu.

\section{Relevansi Undang-Undang Simbur Cahaya dengan Kepemimpinan Saat ini}

Kepala Desa merupakan seseorang yang memimpin dalam sebuah desa, sementara kepemimpinan kepala desa adalah unsur terpenting untuk kemajuan suatu desa baik dari segi pemikiran masyarakatnya maupun pembangunan yang ada di desanya. Adapun dalam melaksanakan tugasnya sebagai seorang pemimpin, kepala desa tidak bisa melakukannya sendiri atau dalam artian tanpa adanya dukungan serta partisipasi dari masyarakat yang dipimpinnya.

Seorang pemimpin dalam proses menyelenggarakan masa kepemimpinannya mempunyai serangkaian visi dan misi serta pedoman supaya dalam masa kepemimpinannya tersebut dapat berjalan baik dan terarah. Adapun kepala desa memiliki pedoman yaitu yang mengatur tentang pemerintahan desa yang dimuat dalam UndangUndang Nomor 6 Tahun 2014. Yang mana jauh sebelum Undang-Undang ini di berlakukan dalam suatu desa, terdapat serangkaian Undang-Undang yang pernah diterapkan, meliputi: Kitab Simbur Cahaya atau dikenal dengan Undang-Undang Simbur Cahaya, UU Nomor 19 Tahun 1965, dan UU Nomor 5 Tahun 1979.

Dari serangkaian Undang-Undang yang pernah diterapkan di Desa Pajar Bulan tersebut, mempunyai relevansi tersendiri antara yang satu dengan yang lainnya. Berkaitan dengan hal tersebut, bahwa ditinjau dari segi relevansi antara kepemimpinan kepala desa dengan Undang-Undang Simbur Cahaya yang relevan adalah hukum adat (peraturan) setempat yang berlaku di kehidupan masyarakat yang melekat hingga menjadi kebiasaan atau tradisi. Adapun peraturan yang terkandung dalam Kitab Simbur Cahaya tersebut dijadikan sebagai penunjuk dan pedoman.

Dalam hal ini penulis dapat menarik intisari kesimpulan bahwa apabila UndangUndang Simbur Cahaya diterapkan kembali di Desa Pajar Bulan yang berlandaskan kepemimpinan tradisional bahwasanya tidak lagi relevan, yang mana aturan dari UndangUndang Simbur Cahaya yang sampai sekarang ini masih diterapkan hingga menjadi kebiasaan dan tradisi yaitu aturan yang dimuat pada bab 1 (satu) yang berisi aturan tentang bujang, gadis dan kawin.

Berkaitan dengan hal tersebut, bahwa secara adat dan kebiasaan masyarakat dalam hal tradisi seperti yang disebutkan tadi yaitu beberapa aturan yang dimuat dalam Bab 1 (satu) Undang-undang Simbur Cahaya masih dipakai di kehidupan masyarakat Desa Pajar Bulan. Yang mana berkaitan dengan hal ini juga, bahwa yang perlu digaris bawahi bahwasanya aturan yang sudah menjadi tradisi tersebut masih tetap diterapkan karena aturan tersebut dapat membawa kemaslahan bersama dan sesuai dengan normanorma yang berlaku di masyarakat Desa Pajar Bulan. 
Adapun dari teori otoritas tradisional dan otoritas kharismatik yang dikemukakan oleh Max Weber bahwa korelasinya dengan Undang-undang Simbur Cahaya adalah karena Undang-undang Simbur Cahaya merupakan kumpulan hukum adat yang dalam hal ini berkaitan dengan teori otoritas tradisional, sedangkan otoritas kharismatik berkaitan dengan Undang-undang Simbur Cahaya pada peran figur dan ketokohan Krio tersebut dalam menjalankan perannya sebagai seorang pemimpin.

\section{KESIMPULAN}

Di Desa Pajar Bulan kepemimpinan tradisional yang pernah diterapkan adalah kepemimpinan Krio yang bernaungkan Undang-Undang Simbur Cahaya. Adapun dalam Kitab Simbur Cahaya seorang Krio dikenal dengan sebutan Proatin. Undang-Undang Simbur Cahaya pada masa itu di Desa Pajar Bulan berperan sebagai pedoman yang mengatur dari segala bentuk aspek kehidupan. Berkaitan dengan hal tersebut, bahwa dari berbagai aturan yang ada dalam Undang-Undang Simbur Cahaya yang masih di praktikkan dalam kehidupan masa kini serta terealisasi hingga menjadi tradisi di kehidupan masyarakat Desa Pajar Bulan adalah aturan yang termuat dalam Bab I UndangUndang Simbur Cahaya yaitu tentang aturan bujang, gadis dan kawin.

Sebutan untuk seorang kepala dusun adalah Krio atau dalam Undang-Undang Simbur Cahaya dikenal dengan sebutan Proatin. Yang mana kepala dusun berperan sebagai pemegang amanah untuk memimpin dusun dalam pemerintahan dengan bentuk marga. Adapun mekanisme pemilihan Krio di Desa Pajar Bulan di gelar dengan jalan musyawarah dan mufakat yang dilaksanakan oleh para tokoh masyarakat Desa Pajar Bulan. Yang mana aturan dalam periode kepemimpinan seorang Krio tidak dituliskan dalam Undang-Undang Simbur Cahaya atau dalam kata lain periode kepemimpinan Krio di Desa Pajar Bulan berjalan dengan apa adanya atau dalam kata lain sesuai dengan keinginan Krio itu sendiri.

Undang-Undang Simbur Cahaya yang di dalamnya terkandung beberapa nilai kepemimpinan yang dalam hal ini dilihat dari naskah atau pasal-pasal yang terkandung di dalamnya. Yang mana nilai kepemimpinan tersebut memberi sebuah gambaran bahwa seorang Krio diharuskan menjadi teladan yang baik bagi masyarakat yang dipimpinnya. Berkaitan dengan hal ini, bahwa dilihat dari demokrasi masa kini juga mengharuskan seorang pemimpin menjadi teladan yang baik bagi masyarakat yang dipimpinnya, mengharuskan seorang pemimpin bersikap bijaksana dalam mengambil suatu keputusan. Berkaitan dengan hal tersebut, bahwa jika demokrasi saat ini berjalan belum sesuai dengan apa yang di harapkan, itu semua bukanlah semata-mata kesalahan dari aturan yang ada, akan tetapi masih banyak terdapat kurangnya kesadaran dari kita untuk menaati dari aturan yang telah di tetapkan.

Adapun mengenai pengaruh yang ditimbulkan dari sistem politik pemerintahan pada masa lalu terhadap sistem politik pemerintahan saat ini tidaklah memperlihatkan sesuatu yang tampak dipengaruhi. Melainkan tatanan politik pemerintahan pada masa lalu tersebut dijadikan kenangan, sejarah serta pelajaran yang sangat berharga di Desa Pajar Bulan. Yang mana masa peralihan dari kepemimpinan Krio kepada kepemimpinan kepala desa tidak menampakkan pengaruh yang signifikan. Sebab kepemimpinan kepala desa juga tidak terlepas dari karisma dan peran figur dari seorang pemimpin itu sendiri. Ditinjau dari segi relevansi antara kepemimpinan kepala desa dengan Undang-Undang Simbur Cahaya yaitu yang relevan adalah hukum adat (peraturan) setempat yang berlaku di kehidupan masyarakat yang melekat hingga menjadi kebiasaan atau tradisi. Adapun 
Bela Fitria \& Otoman, Kepemimpinan Tradisional dalam UU Simbur Cahaya di Desa Pajar Bulan Tanjung Batu Ogan Ilir, Ampera: A Research Journal on Politics and Islamic Civilization, Vol. 2 No. 2 April 2021

peraturan yang terkandung dalam Kitab Simbur Cahaya tersebut dijadikan sebagai penunjuk dan pedoman. 


\section{DAFTAR PUSTAKA}

Adiwilaga, Rendy. 2018. Kepemimpinan Pemerintahan Indonesia, Yogyakarta: Penerbit Deepublish.

Ahyani, "Relevansi Tradisi Masyarakat Desa Tebedak Kecamatan Payaraman Kabupaten Ogan Ilir dalam Aturan Dusun dan Berladang dengan Undang-Undang Simbur Cahaya”. (Palembang: Skripsi Fakultas Adab dan Humaniora IAIN RF, 2014).

Alfan, M. Alfian. 2009. Menjadi Pemimpin Politik. Jakarta: Gramedia Pustaka Utama.

Aly, Salman. 1993. Hukum Islam di Kesultanan Palembang. Laporan Penelitian (Palembang: Balai Penelitian IAIN Raden Fatah).

Amin, Ali dkk. 2001. Kompilasi Adat Istiadat Kabupaten Ogan Komering Ilir. Pemerintah Provinsi Sumatera Selatan.

Berlian, Saudi. 2000. Pengelolaan Tradisional Gender, Telaah Keislaman atas Naskah Simboer Tjahaja, Jakarta: Millenium.

Berlian, Saudi. 2000. Simbur Cahaya dan Masalah Kekerasan, dalam Zulkifli dan Abdul Karim Nasution (peny.), Islam dalam Sejarah dan Budaya Masyarakat Sumatera Selatan, Palembang: UNSRI.

Bungin, Burhan. 2010. Penelitian Kualitatif: Komunikasi, Ekonomi, Kebijakan Publik dan Ilmu Sosial Lainnya, Jakarta: Kencana.

De Faille, P. de Roo. 1971. Dari Zaman Kesultanan Palembang. Diterjemahkan oleh Soegarda Poerbakawadja, Jakarta: Bhratara.

Kenca, Inu. 2008. Ilmu Pemerintahan. Jakarta: Bumi Aksara.

Koentajaningrat, 1990. Metode-metode Penelitian Masyarakat. Jakarta: Gramedia.

Labolo, Muhadam. 2011. Memahami Ilmu Pemerintahan (Suatu Kajian, Teori, Konsep dan Pengembangannya). Jakarta: Rajawali Press.

M. Siahaan, Hotman. 1986. Pengantar Ke Arah Sejarah dan Teori Sosiologi. Jakarta: Erlangga.

Mayasari, Evi "Aturan Marga dalam Undang-Undang Simbur Cahaya “. Skripsi (Palembang: Fakultas Adab dan Humaniora IAIN RF, 2002).

Noer, Deliar. 2003. Islam dan Politik. Jakarta: Yayasan Risalah.

P Siagian, Sondang. 2010. Teori dan Praktek Kepemimpinan, Jakarta: Rineka Cipta.

Pemerintah Provinsi Daerah Tingkat I Sumatera Selatan, 1996. Sejarah Perkembangan Pemerintahan di Daerah Sumatera Selatan

Pulungan, J. Suyuthi. 2014. Fikih Siyasah. Yogyakarta: Penerbit Ombak.

Rahim, Husni. 1998. Sistem Otoritas dan Administrasi Islam: Studi Tentang Penjabat Agama Masa Kesultanan dan Kolonial di Palembang. Jakarta: Logos.

Simbur Cahaya, dalam http://kenabigail.blogspot.com//2012/11/simbur-cahaya.html, diakses pad tanggal 14 Oktober 2020.

Sugiono. 2018. Metode Penelitian Kuantitatif dan Kualitatif. CV. Bandung.

Sujarweni, Wiratna. 2019. Metodologi Penelitian. Yogyakarta: Pustakabarupress.

Sukupenesak.blogspot.com (diakses pada tanggal 28 September 2020).

Suryabrata, Sumadi. 2018. Metodologi Penelitian. Depok: Rajagrapindo Persada.

Suwandi, 2007. Partisipasi Masyarakat Hukum Adat dalam Upaya Menumbuhkembangkan Secara Dinamis Adat dan Budaya Khas Daerah, Manfaatnya Bagi Pembangunan Manusia (Human Development), Lembaga Penelitian, Pengkajian dan Pengembangan Sejarah dan Budaya Daerah Kabupaten Musi Rawas-Kota Lubuk Linggau.

Webber, Max. 2001. Charisma And The Disenchanment Of The World. PA: Xlibris. 
Bela Fitria \& Otoman, Kepemimpinan Tradisional dalam UU Simbur Cahaya di Desa Pajar Bulan Tanjung Batu Ogan Ilir, Ampera: A Research Journal on Politics and Islamic Civilization, Vol. 2 No. 2 April 2021

Zainudin, Muhadi dan Abd. Mustaqim. 2002. Studi Kepemimpinan Islam, Telaah Normatif dan Historis, Yogyakarta: Al-Muhsin Press.

Zainudin, Muhadi. 2012. Studi Kepemimpinan Islam. Yogyakarta: Sukapress. 